\title{
Multiple conceptualizations of nature are key to inclusivity and legitimacy in global environmental governance
}

Luca Coscieme $^{\mathrm{a}, *}$, Håkon da Silva Hyldmo ${ }^{\mathrm{b}}$, Álvaro Fernández-Llamazares ${ }^{\mathrm{c}}$, Ignacio Palomo ${ }^{\mathrm{d}}$, Tuyeni H. Mwampamba ${ }^{\mathrm{e}}$, Odirilwe Selomane ${ }^{\mathrm{f}, \mathrm{g}}$, Nadia Sitas ${ }^{g}$, Pedro Jaureguiberry ${ }^{\mathrm{h}}$, Yasuo Takahashi ${ }^{1}$, Michelle Lim ${ }^{j}$, Maria P. Barral ${ }^{\mathrm{k}}$, Juliana S. Farinaci ${ }^{1}$, Julio Diaz-Josém ${ }^{m}$, Sonali Ghosh ${ }^{\mathrm{n}}$, Joyce Ojino ${ }^{\circ}$, Amani Alassaf ${ }^{\mathrm{p}}$, Bernard N. Baatuuwie ${ }^{\mathrm{q}}$, Lenke Balint ${ }^{\mathrm{r}}$, Zeenatul Basher, ${ }^{\mathrm{s}}$ Fanny Boeraeve ${ }^{\mathrm{t}}$, Sugeng Budiharta ${ }^{\mathrm{u}}$, Ruishan Chen ${ }^{\mathrm{v}}$, Maylis Desrousseaux ${ }^{\mathrm{w}}$, Gregory Dowo $^{\mathrm{x}}$, Catherine Febria ${ }^{\mathrm{y}}$, Houda Ghazi ${ }^{\mathrm{z}}$, Zuzana V. Harmáčková ${ }^{\mathrm{AA}}$, Rodolfo Jaffe ${ }^{\mathrm{BB}}$, Mphatso M. Kalemba ${ }^{\mathrm{CC}}$, Cosmas K. Lambini ${ }^{\mathrm{DD}}$, Felicia P.S. Lasmana ${ }^{\mathrm{EE}}$, Assem A.A. Mohamed ${ }^{\mathrm{FF}}$, Aidin Niamir $^{\mathrm{GG}}$, Patricio Pliscoff ${ }^{\mathrm{HH}}$, Rahat Sabyrbekov ${ }^{\mathrm{II}}$, Uttam B. Shrestha ${ }^{\mathrm{JJ}}$, Aibek Samakov ${ }^{\mathrm{KK}}$, Anna A. Sidorovich ${ }^{\mathrm{LL}}$, Laura Thompson ${ }^{\mathrm{MM}}$, Mireia Valle ${ }^{\mathrm{d}, \mathrm{NN}}$

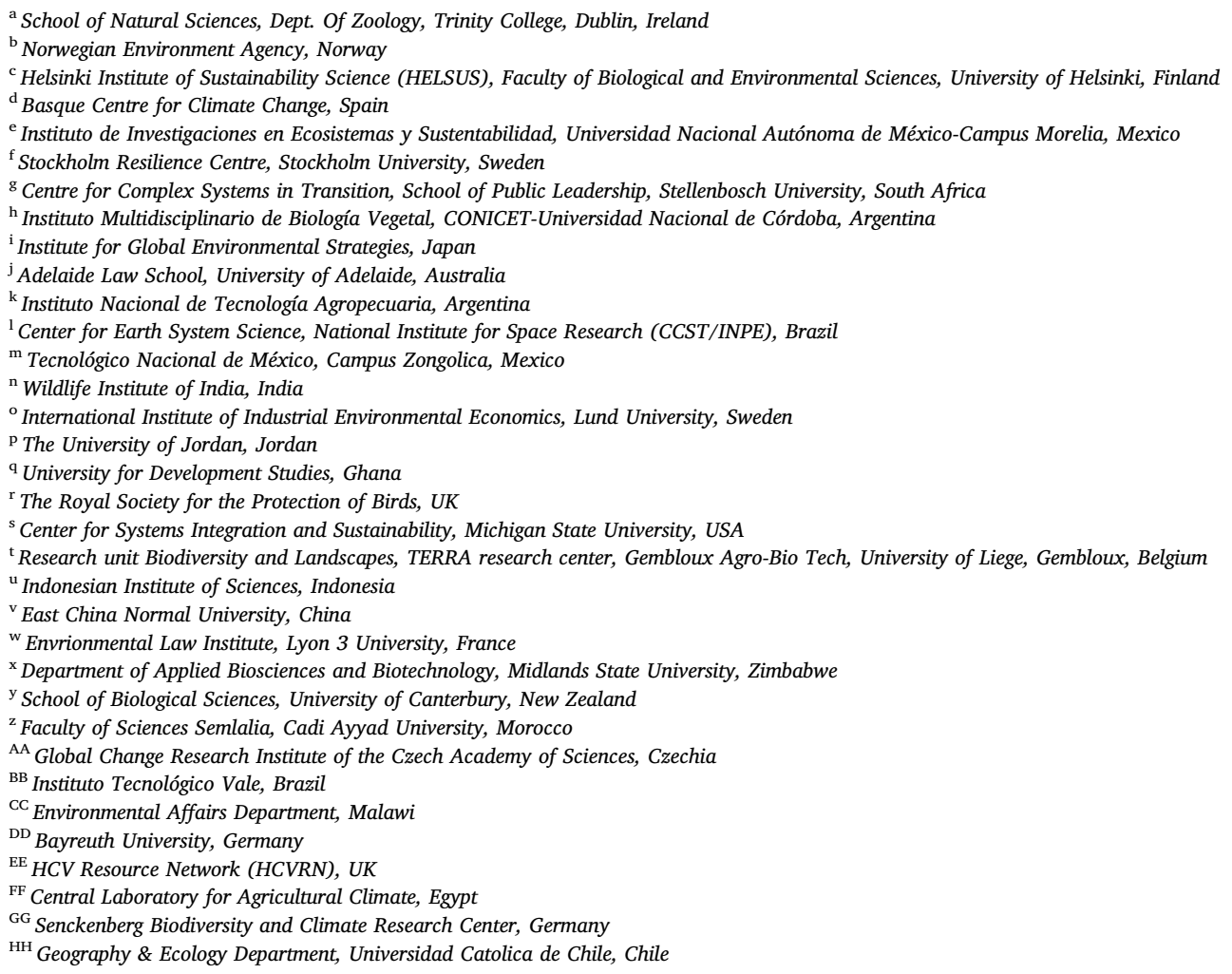

\footnotetext{
* Corresponding author.

E-mail address: lucaaq@gmail.com (L. Coscieme).
} 


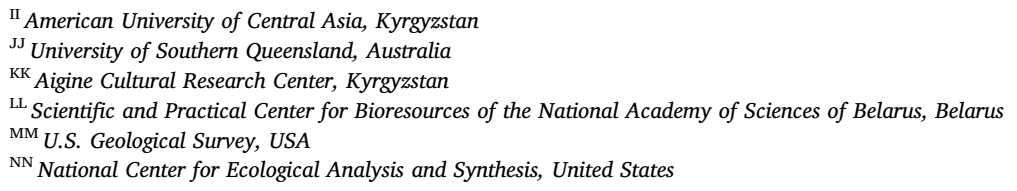

\section{A R T I C L E I N F O}

\section{Keywords:}

Earth jurisprudence

Indigenous peoples

Knowledge systems

Ontological turn

Rights of nature

Science-policy process

\begin{abstract}
A B S T R A C T
Despite increasing scientific understanding of the global environmental crisis, we struggle to adopt the policies science suggests would be effective. One of the reasons for that is the lack of inclusive engagement and dialogue among a wide range of different actors. Furthermore, there is a lack of consideration of differences between languages, worldviews and cultures. In this paper, we propose that engagement across the science-policy interface can be strengthened by being mindful of the breadth and depth of the diverse human-nature relations found around the globe. By examining diverse conceptualizations of "nature" in more than 60 languages, we identify three clusters: inclusive conceptualizations where humans are viewed as an integral component of nature; non-inclusive conceptualizations where humans are separate from nature; and deifying conceptualizations where nature is understood and experienced within a spiritual dimension.

Considering and respecting this rich repertoire of ways of describing, thinking about and relating to nature can help us communicate in ways that resonate across cultures and worldviews. This repertoire also provides a resource we can draw on when defining policies and sustainability scenarios for the future, offering opportunities for finding solutions to global environmental challenges.
\end{abstract}

\section{Introduction}

Global environmental policies and international agreements necessitate a shared understanding of the environmental challenges to be addressed and common goals and targets to be achieved (Costanza et al., 2016; Mortensen and Petersen, 2017; Wright, 2002). Addressing global environmental challenges can be most effective with the participation of, and successful dialogue and cooperation with, academics, the private/business sector, policy-makers, civil societies and local constituencies. Considering differences between languages, worldviews and cultures is essential to achieve fruitful engagement and dialogue in different contexts (Breslow et al., 2016; Costa et al., 2014; Ostrom, 2009; Welch et al., 2005). This necessity is reflected, for example, within the Intergovernmental Science-Policy Platform on Biodiversity and Ecosystem Services (IPBES), which is working explicitly on reaching agreement on terms and epistemologies, stressing the importance of integrating a range of hetereogeneous worldviews and practices (Díaz et al., 2015a, 2015b; Turnhout et al., 2012; Larigauderie et al., 2016; Reuter et al., 2016; Lambini and Heubach, 2017) and undertaking a methodological assessment on the diverse conceptualisation of multiple values of nature (IPBES, 2015; Pascual et al., 2017).

Different peoples and cultures live in and with nature in different ways. Cultural and environmental anthropologists have shown that there are many different ways of understanding nature and that these diverse conceptualizations have been shaped by different historical and cultural contexts (Descola and Gisli, 1996; Ellen and Fukui, 1996; Posey, 1999). These differences are reflected in different languages and in the many ways people from different cultures describe nature. Throughout history, specific conceptualizations of nature have been adopted over others, reflecting power struggles and geopolitical processes linked to the governance of nature (Escobar, 1998; Van Noordwijk et al., 2014). It has been argued recurrently that mobilizing different knowledge systems for environmental governance can be achieved through open channels of communication between different knowledge-holders (Cash et al., 2003; Fernández-Llamazares et al., 2015). Global environmental governance can benefit from acknowledging the diversity of values that different worldviews offer, including the views of Indigenous and local knowledge-holders (Tengö et al., 2014, 2017; Nahuelhual et al., 2018). Key messages and policy-options from scientific assessments and research can stimulate the formulation of policies that better resonate across a wide range of cultural, epistemic and ontological contexts. The diversity of conceptualizations of nature across the world constitutes an important resource for envisioning multiple ways to govern human-nature relations to create sustainable futures.

Changes in how relationships between people and nature are viewed have consequences for environmental science and policy (Mace, 2014). Since the 1960s the prevailing view of conservation has changed several times from a tendency to treat people and nature as separate ("nature for itself" and "nature despite people" approach), to a conservation thinking which recognizes nature benefits to humans ("nature for people" approach) (Mace, 2014; Schoolenberg et al., 2018). All these conservation framings, however, seem to be based on the assumption that there is just one single concept of nature. They do not dig into the different cultural understandings of nature across the world, for example by investigating how this is reflected by language, as one important cultural tool and identifier.

In this paper we bring together research on the evolution of conservation science and practice and anthropology research, exploring different conceptualisations of 'nature' in more than 60 languages. Building on this body of research and existing classifications, we identify three broad conceptual categories (i.e., inclusive natures, exclusive natures and deifying natures). We argue that global environmental governance can be strengthened by recognising fundamental differences and a greater plurality in how nature is conceptualized across the planet. Ensuring the integration of this diversity into policies and agreements could lead to more effective environmental policies.

Our classification is intended to be adaptable to different interpretations. It constitutes a "map", not necessarily restrictive but rather orientative, useful to understand the broad range of conceptualizations of nature co-existing in the world. It can be used as a basis for fruitful debate around promoting inclusivity and legitimacy of different knowledge systems and worldviews in environmental policymaking.

\section{Nature is multiple and always in the making}

While in a number of disciplines there is increasing emphasis on the role of language in shaping our perceptions of the world, the issue has insofar received limited attention across environmental sciences as a whole (Döring and Zunino, 2014). Despite much practical environmental knowledge is actually non-linguistic, we argue that language is 
an interactive entitiy or process that forms an intrinsic part of humannature relations. Languages are both shaped by the world around us and shape our patterns of actions: "language is interconnected with the world; it both constructs and is constructed by it" (Mühlhäusler, 2003). The multiplicity of languages around the world can be seen as emerging through a set of complex interlinkages with nature while at the same time structuring our relations with it.

Fisher (1984) suggests that the human species can be thought of as Homo narrans: human societies, relationships and sense of self are constructed through stories. For Okri (1996), "stories are the secret reservoir of values: change the stories that individuals or nations live by, and you change the individuals and nations themselves". Stories are articulations of our perceptions and legitimate and inspire our actions (Kuletz, 1998), so that the stories we (re)tell, and the language we use to do so, shape our view of the world and become the stories-we-live-by, establishing the frames of reference through which we make sense of the roles, structures and relationships in the world (Stibbe, 2015; Lakoff, 2010). Words, terms, ideas, songs, images, and stories about nature have direct impacts on how nature is perceived and communicated (Satterfield and Slovic, 2004; Coscieme, 2015). Importantly, such stories also include the ones told by scientists (Latour, 2009).

The ecological implications of the stories we tell and the language we use to tell them have been explored in a growing body of ecolinguistics literature, spanning explorations of how grammar, specific words and overarching stories about human beings and the world in which we live contribute to construe reality (Alexander and Stibbe, 2014). Schultz (2001) shows how language to describe economic activities fails to highlight ecological aspects, such as when using 'land clearing' with a positive connotation, rather than a more accurate description such as 'native vegetation removal'. Rosenfeld (2019) discusses the ecological implications of the use of the words 'weed', when used to describe an undesirable plant, and 'soil', when used as a verb to describe defiling something or making it unclean. Kuletz (1998) explores how the term 'wasteland', defined as "an empty area of land, especially in or near a city, which is not used to grow crops or built on, or used in any way" is used to label permissible locations for storing nuclear waste.
Descriptions of the world as made to be the dominion of human beings support human-nature relations aimed at promoting human welfare at the expense of other species. The "invention" of America by Amerigo Vespucci, as well as the stories told by other European explorers and travellers about uninhabited distant lands, created 'new' continents, landscapes, peoples and 'nature' in ways that legitimated colonial appropriation (Spurr, 1993; Stepan, 2001; Strachan, 2002). Stories about the causes of deforestation and degradation of the Sahel influenced environmental policies in the 1970s and 1980s (Fairhead and Leach, 1996). Indigenous people stories enact more intimate relations between humans and nature. For many Indigenous peoples across the Andes, Pachamama, is an active sentinent being. For the Mowachat/ Muchalaht First Nation, their deceased chief reincarnated in an orca whale that left her pod to stay closer to her people, thus opening a debate on if and how to intervene and relocate her (Blaser, 2013, 2014). Overall, practices building on the complex webs of relationality with nature and spiritual beings common in many Indigenous people knowledge systems result in different relations between nature and humans than the practices building on stories of Earth as being the dominion of human beings (De la Cadena, 2015).

Stories are intertwined in different ways with different languages that have emerged in close relation to the physical worlds of their speakers (Mühlhäusler, 2003). Different languages may hold rich discourses that encode what their speakers have learned about living sustainably in the local environment. Scientific studies and environmental assessments describing local socio-ecological settings in terms and language foreign to the language spoken by local communities could misinterpret or misrepresent peoples' understandings of nature. Mühlhäusler (2001) suggests that one of the principal reasons slowing down progresses in environmental sciences is monolingualism and monoculturalism, showing how many different interpretations and many different languages are necessary for solving global environmental challenges. Several authors have claimed that, given that different languages reflect different cultural understandings of nature, increasing linguistic diversity in the environmental sciences could help to broaden and diversify the values underpinning conservation practice (Niles and Tachimoto, 2018; Rosenfeld, 2019) and challenge

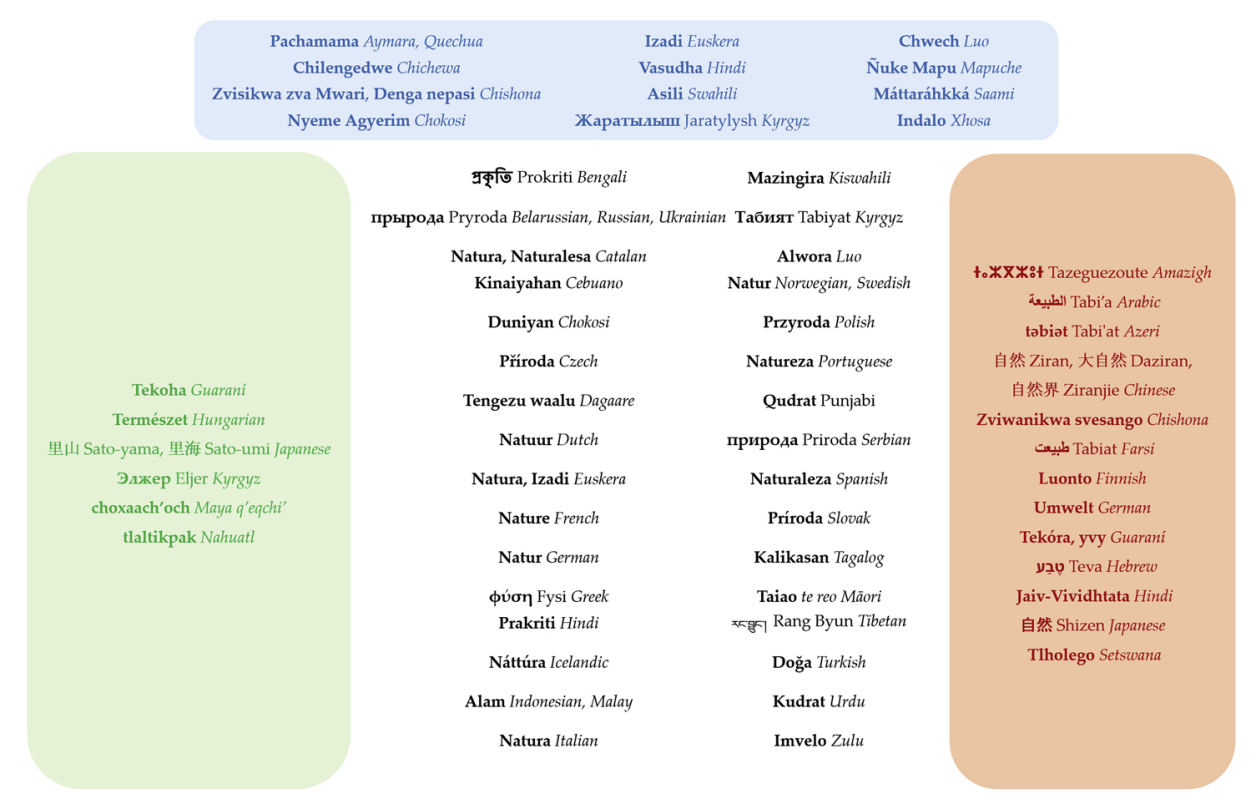

deifying 'natures' : nature is defined within a spiritual realm

conceptualizations that assume a more inclusive, non-inclusive, or spiritual dimension depending on the context of use and individual
perspective
Fig. 1. A sample of multiple conceptualizations of nature in different languages along a continuum from non-inclusive natures that mostly exclude humans from the concept of nature, to inclusive natures that include humans. Deifying natures equate nature to the act of one or multiple deities. Dotted lines highlight that one conceptualization can be used with different degrees of inclusiveness, and assume a spiritual connotation, depending on the context and individual interpretations. 
hegemonic patterns of knowledge production (Meneghini and Packer, 2007; Tietze and Dick, 2012).

In sum, the stories we tell, the language we tell them in, and the words used to tell them are instrumental in the cultural production of nature and in shaping human-nature relations. These stories help us identify different communities, sharing a number of understandings about what does exist and how the natural, human and spiritual worlds are articulated (Mathez-Stiefel et al., 2007). When talking about stories, we include those told by scientists and scholars through their research and publications. The impact of these stories will in part depend on the degree to which they resonate with other peoples' conceptualizations of nature. Maximising the impact that stories have, may entail crafting stories that respect and consider different views and understandings of nature (e.g., Green et al., 2015; Fernández-Llamazares and Cabeza, 2018). Furthermore, as stories partake in creating realities, we need to be mindful that they can also reinforce unsustainable or undesireable worlds (Blaser, 2014). Similarly, local languages and knowledges may hold important resources for imagining and implementing ecologically sustainable human-nature relations.

\section{Exploring multiple natures}

To explore the multiplicity of different natures across the world and stimulate discussion we collected conceptualizations of 'nature' in a sample of 63 different languages, spoken by more than $60 \%$ of the global population (Fig. 1). The methodology employed involved the following steps: 1) native speakers of different languages were invited by the authors to answer in writing the question: "how would you translate the word 'nature' in your language?" and elaborate on the meaning and use of the term (or terms) they indicated, with a particular focus on how it defines human-nature relationships; 2) the responses were analysed and grouped following an inductive approach and considering the results of similar excercises (e.g. Mace, 2014; Schoolenberg et al., 2018) and a vast body of cultural and environmental anthropology research; and, 3) the analysis was shared with the native speakers to confirm their understanding of the translation and its interpretation in a specific conceptualization category.

The responses reflect individual interpretations and uses of the terms. The authors are a mix of interdisciplinary researchers and policymakers who are native speakers of more than two thirds of the languages represented in the survey.

Three broad and possibly overlapping categories (Fig. 1) emerged from our analysis: 1) Inclusive (i.e., human beings are an integral part of nature); 2) Non-inclusive (i.e., human beings are not an integral part of nature, implying some sort of human-nature dichotomy); and 3) Deifying (i.e., nature is defined within a spiritual realm).

Through the analysis, we aim at illustrating the considerable breadth and depth of the multiple conceptualizations of nature existing on the planet, as an entrypoint to reflect on the importance of being mindful of the multiple ways of relating to and governing nature (Díaz et al., 2018). We recognize that the three categories we identified by analyzing the responses do not represent all possible categories that could be derived. Furthermore, the inclusion of a conceptualization in a specific category should not be understood in a strict sense. We do not imply that inclusiveness (of humans in nature) and a spiritual dimension can be explicitly quantified to a certain degree. This representation aims at highlighting that a continuum exists along them. A fourth 'category' includes conceptualizations that are not entirely and unequivocally relatable to any of the other three.

Inclusive conceptulizations of nature present human beings and their systems (e.g., cities and farms) as part of nature. This is the case of the Dagaare (Ghana) term Tengezu waalu that refers to 'all the living and non-living things' and also of the Hungarian word Természet, a conceptualization of nature that literally means 'everything'. Even more specific in this vein is the Kyrgyz term Элжер [Eljer], referring to 'people and the land', thus characterizing humans as a natural component integrated within nature, i.e. together with the land.

Inclusive conceptualizations of nature feature prominently in many Indigenous languages (Atleo, 2011; Kohn, 2013; Porter, 2014; Zent, 2015). For example, Indigenous ontologies in Latin America move away from the representation of an abstract and universal nature towards recognition of 'Earth beings' as animate manifestations of nature (De La Cadena, 2010). Similarly, the concept of iwigara, or the total connectedness of all life amongst the Raramuri peoples of Mexico, entails a view of nature as relatives sharing space (Salmón, 2000). Importantly, the link between Indigenous conceptualizations and inclusive practices are reflected in the remarkable overlap between Indigenous territories and the world's remaining areas of high biodiversity (Sheil et al., 2015; Schuster et al., 2018; Bertzky et al., 2012; Garnett et al., 2018).

Non-inclusive natures exclude human beings implicitly or explicitly from what is intended as nature, implying some sort of nature-culture dichotomy. In non-inclusive natures, humans are considered as clearly distinct from the rest of the natural world. Examples of this distinction are clear in the Chinese language, in which the concept of nature can be expressed as 自然 [Ziran], i.e. 'natural', referring to pristine or untouched environment. Similarly 大自然 [Daziran], i.e. 'big natural', refers to everything not made by humans, and 自然界 [Ziranjie], i.e. 'natural world', refers to everything non-human.

In Japanese the term 自然 [Shizen] uses the same characters, although pronounced differently, as the Chinese 'Ziran', also referring to pristine, or unmodified environment in which humans evolved. However, more specifically, 'Shizen' conceptualizes nature as superior to and beyond human control, sometimes causing the destruction of human society, e.g. earthquakes, tsunamis, volcanic eruptions, storms and typhoons. As the importance of production landscapes and seascapes has become recognized in the nature conservation discourse in Japan, the word 里山 [Sato-yama] or the word 里海 [Sato-umi] have become frequently used. They imply a more inclusive connotation of nature referring to landscapes where reciprocally beneficial relationships between nature and people exist.

In terms of 'deifying' conceptualizations of nature, nature is perceived as a Goddess or a God. Many cultures around the world further distinguish between understandings of nature as something created (or donated) by a deity, and god or gods that are the very personification of nature. The latter is the case of Vasudha, i.e., 'Mother Earth', in Bengali (Hindi), or the Quechua and Aymara Pachamama, or the Mapuche Ñue Mapu. Nature is conceptualised as 'God's gift', Nyeme Agyerim, in Chokosi (Ghana), with humans as receivers of the gift. References to nature as the result of God's creation are found in many cultures: the Chewa (Malawi) Chilengedwe (the Creation) the Shona (Zimbabwe) Zvisikwa zva Mwari (God's Creation), the Xhosa Indalo (the Creation, excluding humans) and Denga nepasi (Heaven and Earth), the Kyrgyz Жаратылыш [Jaratylysh] (everything that was created), the Luo (Kenya) Chwech (the Creation). Many of these conceptualizations have a holistic character, encompassing non-human living organisms, ancestors, deities and their intertwined histories (e.g., Berkes, 1999; Descola, 2005).

Deifying conceptualizations of nature could assume an inclusive or exclusive worldview in different cultures and contexts of use. In South Asia and especially in India, nature is sacred and present in daily practices (Guha, 2014). The religious and spiritual values in the culture of Ahimsa (to live and let live) are shaped by how humans treat nature (Habib, 2010). Elephants are revered as a god (Ganesh baba), and vultures are sacred for excarnation among Zoroastrians. Sarus cranes are symbols of marital fidelity, and this intimate inclusion of nature into religious and spiritual values have helped the conservation of these species. Overall, "India's unity as a nation has been firmly constituted by the sacred geography it has held in common and revered", and this worldview "continues to anchor millions of people in the imagined landscape of their country" (Eck, 2012).

In some cases, the concept of nature is directly linked to specific environments. This is the case of the Shona (Zimbabwe) Zviwanikwa 
svesango, a conceptualization of nature that refers to forest resources/ biodiversity. Another example is the Amazigh [Tazeguezoute], meaning 'greenery', which evokes environments with a specific 'chromatic' connotation.

Many conceptualizations of nature have been lost over time. This is particularly the case for languages that suffered a declining trend in use, especially when Indigenous and local languages have been replaced by non-native languages in the formal education system (Amano et al., 2014; Harmon and Maffi, 2002; Moseley, 2010; Stepp et al., 2004). Languages that emerged from the fusion of multiple languages out of necessity for goods trade, slave trade, or other historical conditions (e.g., creole, patua, swahili) tend to refer to simplified and utilitarian conceptualizations of nature. For example, in Swahili, nature as a stand alone term is non-existent although it tends to be translanted literally as 'original' (asili) with connotations of 'unaltered by humans', i.e. 'natural' or 'environment' (mazingira). In the absence of a single term that captures the idea of a space that is 'natural', Swahili speakers tend to slip in a Swahili version of the English word 'nature', i.e. necha.

\section{Implications for policy development}

Policy is the institutionalization of behaviours and practices (Clark, 2002; Game et al., 2015). Different conceptualizations of nature reflect different behaviours and practices and have laid the ground for different policy approaches towards nature conservation and environmental governance. Here, we discuss how the three conceptualizations of nature we present are often related with specific conservation approaches. For instance, laws promoting the recognition of the Rights of Nature have been, in most cases, heavily influenced by Indigenous Peoples' philosophies which place nature at the center of all life (Akchurin, 2015; Borràs, 2016). The Bolivian Law of Mother Earth (Law 071; $21^{\text {st }}$ December 2010; Gaceta Oficial del Estado Plurinacional de Bolivia) draws on Andean spiritual traditions seeing Mother Earth (or Pachamama) as a sacred deity, and entitles nature with rights as a collective subject of interest (Pacheco, 2014; Kauffman and Martin, 2016). In addition to defining a set of morals for environmental governance, the Law of Mother Earth aims at preventing "human activities causing the extinction of living populations, the alterations of the cycles and processes that ensure life, or the destruction of livelihoods, including cultural systems that are part of Mother Earth" (Article 8); while people, and public and private legal entities, have the duty to "uphold and respect the rights of Mother Earth" (Article 9) (Humphreys, 2017). Similarly, by granting legal status to the Whanganui River, New Zealand found an innovative way to honour and respect the Maori traditional worldview of nature as "an indivisible and living whole" (Hutchinson, 2014; Strack, 2017).

In contexts whereby multiple natures co-exist, appropriate policies are designed to construct an integrated discourse and set of practices, from a view of 'multiple cultures associated to a single nature' to a new view of 'multiple natures related with multiple cultures'. Since language is one of the main cultural instruments, the challenge for policy makers (as well as natural scientists) is to implement initiatives and communicate their knowledge to different cultures and in different languages. For example, the contextualized application of initiatives such as the Earth Charter in Guatemala with Maya-Q'eqchi' Indigenous communities integrates values and other aspects inherent to the Mayan worldview where balance, respect and reciprocity with the Earth and the cosmos are central to strengthen an environmental-cultural educational process. The Earth Charter principles were translated in Maya-Q'eqchi' to students and teachers highlighting the links between these global values and their local context. From this initiative, numerous other voluntary conservation initiatives have emerged in educational centers, such as community reforestation trainings, cleaning campaigns of water bodies, recycling and sustainable consumption campaigns (Meda and Hermes, 2014).

The notion of inclusive nature implies in many instances a more equal and integrated conception of the value of human beings and nature, and often expands the frontiers of who is entitled to have specific rights, including a broad range of non-human beings such as animals, plants, or entire ecosystems. The Satoyama Initiative recognizes the notion of reciprocity with nature, integrating conservation and the sustainable use of biodiversity in production landscapes (Takeuchi, 2010). Similarly, biocultural approaches to conservation reflect the coevolutionary dynamics of interdependent social-ecological systems (e.g. Gavin et al., 2015, 2018; Buizer et al., 2016; Sterling et al., 2017; Fernández-Llamazares and Cabeza, 2018). In contrast, in cultural contexts with non-inclusive natures, a nature-culture divide is often enshrined in nature conservation legislation. 'Fortress conservation' measures and strict Protected Areas are perhaps the most paradigmatic examples in this vein (Brockington, 2002; Siurua, 2006; De Santo et al., 2011). Policy debates around 'land sharing' and 'land sparing' (e.g., Phalan et al., 2011, 2016; Balmford et al., 2018; Lamb et al., 2016) or around the 'Nature Needs Half' Initiative (e.g., Noss et al., 2012; Wuerthner et al., 2015; Wilson, 2016) further reflect the epistemological tensions that emerge when equating nature with wilderness (Fischer et al., 2014; Büscher et al., 2017).

Customary institutions of Indigenous Peoples often recognise the deep connections between nature and people in a more integrated manner (Parotta and Trosper, 2012; Chen and Gilmore, 2015) based on relational values (Jeeva et al., 2006; Clark and Slocombe, 2009; Samakov and Berkes, 2017), kinship-oriented philosophies (Salmón, 2000; Bird, 2011; Aniah and Yelfaanibe, 2016) and a powerful stewardship ethics (Gammage, 2011; Kohn, 2013). The strong overlap between Indigenous territories and biodiversity hotspots in the world today (Gorenflo et al., 2012; Garnett et al., 2018) suggests that we may find inspirations from Indigenous knowledge systems for new stories about nature, for achieving sustainability. Investments in the development of measures and assessments of the level of integration and participation of Indigenous and local communities (e.g., Aichi Target 18) is often considered an urgent priority for environmental policymaking (Tittensor et al., 2014; Reyes-García et al., 2019). Broad inclusion will bring legitimacy to conservation and other environmental policies, assisting policymakers in avoding too narrow representations of the overwhelming diversity of human-nature relations.

Successfully addressing global environmental challenges requires improving sustainability imaginaries and co-designing policies and policy instruments that are more respectful and inclusive of different worldviews. This implies acknowledging nature in its full diversity, including the spectrum of relationships by which humans relate to nature (Díaz et al., 2018). Doing so will promote values around which different interpretations of nature and human-nature relationships can co-exist. This does not necessarily imply reaching consensus amongst different knowledge-holders, but serves as a basis for conversation, stressing the complementarity and the flexibility of the diverse conceptualisations of nature (Dunkley et al., 2018). The consideration of multiple visions and concepts of nature, stemming from heterogeneous worldviews and epistemic and philosophical traditions, can be achieved through mobilizing knowledge in support of culturally-sensitive initiatives for global environmental governance. For example, the IPBES fellowship programme (IPBES, 2019) brings together early-carreer researchers and practitioners from multiple disciplines and cultural contexts, including Indigenous People, supporting the authors of the assessments with the aim of including multiple conceptualizations of nature, as well as an intergenerational and multidisciplinary dimension.

Nature is experienced, represented and conceptualized in a myriad of ways (Niles and Tachimoto, 2018). This influences the choice of the tools we use to study it (both qualitative and quantitative), how we bring it into policy and ultimately how we will (or not) be its stewards. Practical field guides to participatory and other research tools such as the ARPNet Dilly Bag for use by Aboriginal research practitioners in Australia (Sithole, 2012) are good examples to replicate and implement for improving communications with other cultures, learn about their conceptualization of nature and consider these in policy initiatives. 


\section{Conclusions}

Beyond reflecting the beautiful and rich variety of human relationships with nature and being one fundamental aspect of humans' collective knowledge of the world, different conceptualizations of nature influence behavior and actions at individual, institutional and societal levels. Understanding how other people perceive nature opens a space for deliberation and participation, and offers new options and tools for cooperation to address environmental challenges.

Environmental policy can include a comprehensive discussion of, and dialogue among, multiple conceptualizations of nature and engage a diverse pool of inter- and transdisciplinary scientists from as many different countries and cultures as possible, including Indigenous Peoples, local communities and other underrepresented groups. In addressing different conceptualizations of nature we will increase our ability to tell, hear and learn from, stories that resonate across cultural, social and political boundaries. Such stories will extend the outreach of international research initiatives through broadening the scope and significance of the results, strengthening impacts and communicability towards a range of people and policy makers around the world.

\section{Declaration of Competing Interest}

The authors declare that no conflict of interest holds regarding the research and the content related to the manuscript

\section{Acknowledgement}

We are grateful to Eduardo Brondizio and Egleé Zent for useful discussions and comments on an earlier draft of this publication. The authors are grateful to Ingunn Storrø and to the IPBES Technical Support Unit for Capacity Building, whose activities and efforts inspired the original framing of this research. We wish to thank Felice van der Plaat for coordinating the revisioning of this paper prior to submission. LC is funded by an IRC/Marie Skłodowska-Curie CAROLINE Postdoctoral Fellowship (IRC-CLNE/2017/567). Any use of trade, firm, or product names is for descriptive purposes only and does not imply endorsement by the U.S. Government.

\section{References}

Akchurin, M., 2015. Constructing the rights of nature: constitutional reform, mobilization, and environmental protection in Ecuador. Law \& Social Inquiry 40, 937-968. https://doi.org/10.1111/1si.12141.

Alexander, R., Stibbe, A., 2014. From the analysis of ecological discourse to the ecological analysis of discourse. Language Sciences 41, 104-110. https://doi.org/10.1016/j langsci.2013.08.011.

Amano, T., Sandel, B., Eager, H., Bulteau, E., Svenning, J.-C., Dalsgaard, B., Sutherland, J., 2014. Global distribution and drivers of language extinction risk. Proceedings of the Royal Society B 281https://doi.org/10.1098/rspb.2014.1574. 20141574.

Aniah, P., Yelfaanibe, A., 2016. Learning from the past: the role of sacred groves and shrines in environmental management in the bongo District of Ghana. Environmental Earth Sciences 75, 916. https://doi.org/10.1007/s12665-016-5706-2.

Atleo, E.R., 2011. Principles of Tsawalk: an Indigenous Approach to Global Crisis. University of British Columbia Press, Vancouver, Canada.

Balmford, A., Amano, T., Bartlett, H., Chadwick, D., Collins, A., Edwards, D., Eisner, R., 2018. The environmental costs and benefits of high-yield farming. Nature Sustainability 1, 477-485. https://doi.org/10.1038/s41893-018-0138-5.

Berkes, F., 1999. Sacred Ecology. Taylor and Francis, Ann Arbor.

Bertzky, B., Corrigan, C., Kemsey, J., Kenney, S., Ravilious, C., Besançon, C., Burgess, N., 2012. Protected Planet Report 2012: Tracking Progress Towards Global Targets for Protected Areas. Gland, Switzerland: IUCN. UNEP-WCMC, Cambridge, UK.

Bird, D.R., 2011. Wild Dog Dreaming: Love and Extinction. University of Virginia Press, Charlottesville.

Blaser, M., 2013. Ontological conflicts and the stories of peoples in spite of Europe. Current Anthropology 54, 547-568. https://doi.org/10.1086/672270.

Blaser, M., 2014. Ontology and indigeneity: on the political ontology of heterogeneous assemblages. Cultural Geographies 21, 49-58. https://doi.org/10.1177/ 1474474012462534.

Borràs, S., 2016. New transitions from human rights to the environment to the rights of nature. Transnational Environmental Law 5, 113-143. https://doi.org/10.1017/ S204710251500028X.

Breslow, S.J., Sojka, B., Barnea, R., Basurto, X., Carothers, C., Charnley, S., et al., 2016. Conceptualizing and operationalizing human wellbeing for ecosystem assessment and management. Environmental Science \& Policy 66, 250-259. https://doi.org/10. 1016/j.envsci.2016.06.023.

Brockington, D., 2002. Fortress Conservation: The Preservation of the Mkomazi Game Reserve, Tanzania. Indiana University Press, Bloomington.

Buizer, M., Elands, B., Vierikko, K., 2016. Governing cities reflexively - the biocultural diversity concept as an alternative to ecosystem services. Environmental Science \& Policy 62, 7-13. https://doi.org/10.1016/j.envsci.2016.03.003.

Büscher, B., Fletcher, R., Brockington, D., Sandbrook, C., Adams, W.M., et al., 2017. Halfearth or whole earth? Radical ideas for conservation, and their implications. Oryx 51 , 407-410. https://doi.org/10.1017/S0030605316001228.

Cash, D.W., Clark, W.C., Alcock, F., Dickson, N.M., Eckley, N., Guston, D.H., et al., 2003. Knowledge systems for sustainable development. PNAS 100, 8086-8091. https://doi. org $/ 10.1073 /$ pnas. 1231332100.

Chen, C., Gilmore, M., 2015. Biocultural rights: a new paradigm for protecting natural and cultural resources of indigenous communities. The International Indigenous Policy Journal 6 (3). https://doi.org/10.18584/iipj.2015.6.3.3.

Clark, D.A., Slocombe, D.S., 2009. Respect for grizzly bears: an aboriginal approach for coexistence and resilience. Ecol. Soc. 14 (1), 42.

Clark, T.W., 2002. The Policy Process: a Practical Guide for Natural Resources Professionals. Yale University Press, New Haven, CT.

Coscieme, L., 2015. Cultural ecosystem services: the inspirational value of ecosystems in popular music. Ecosyst. Serv. 16, 121-124. https://doi.org/10.1016/j.ecoser.2015. 10.024.

Costa, A., Foucart, A., Arnon, I., Aparici, M., Apesteguia, J., 2014. "Piensa" twice: on the foreign language effect in decision making. Cognition 130, 236-254. https://doi.org/ 10.1016/j.cognition. 2013.11.010.

Costanza, R., Daly, L., Fioramonti, L., Giovannini, E., Kubiszewski, I., Mortensen, L.F. Wilkinson, R., 2016. Modelling and measuring sustainable wellbeing in connection with the UN sustainable development goals. Ecol. Econ. 130, 350-355. https://doi. org/10.1016/j.ecolecon.2016.07.009.

De La Cadena, M., 2010. Indigenous cosmopolitics in the Andes: conceptual reflections beyond 'politics'. Cultural Anthropology 25, 334-370. https://doi.org/10.1111/j. 1548-1360.2010.01061.x.

De la Cadena, M., 2015. Earth-Beings: Ecologies of Practice Across Andean Worlds. Duke University Press.

De Santo, E.M., Jones, P.S., Miller, A.M.M., 2011. Fortress conservation at sea: a commentary on the chagos marine protected area. Marine Policy 35, 258-260. https:// doi.org/10.1016/j.marpol.2010.09.004.

Descola, P., 2005. Par-delà nature et culture. Gallimard, Paris.

Descola, P., Gisli, P., 1996. Nature and Society: Anthropological Perspectives. Routledge, London, UK.

Díaz, S., Pascual, U., Stenseke, M., Martín-López, B., Watson, R.T., Molnár, Z., et al., 2018. Assessing nature's contributions to people: recognizing culture, and diverse sources of knowledge, can improve assessments. Science 359 (6373), 270-272. https://doi.org/ 10.1126 /science.aap8826.

Díaz, S., Demissew, S., Carabias, J., Joly, C., Lonsdale, M., Ash, N., et al., 2015a. The IPBES conceptual framework - connecting nature and people. Current Opinion in Environmental Sustainability 14, 1-16. https://doi.org/10.1016/j.cosust.2014.11. 002 .

Díaz, S., Demissew, S., Joly, C., Lonsdale, W.M., Larigauderie, A., 2015b. A Rosetta Stone for nature's benefits to people. PLoS Biol. 13 (1), e1002040. https://doi.org/10. 1371/journal.pbio.1002040.

Döring, M., Zunino, F., 2014. NatureCultures in Old and New worlds. Steps towards an ecolinguistic perspective on framing a 'new' continent. Language Sciences 41, 34-40. https://doi.org/10.1016/j.langsci.2013.08.005.

Dunkley, R., Baker, S., Constant, N., Sanderson-Bellamy, A., 2018. Enabling the IPBES conceptual framework to work across knowledge boundaries. International Environmental Agreements 18, 779-799. https://doi.org/10.1007/s10784-0189415-z.

Eck, D.L., 2012. India: A Sacred Geography. Three Rivers Press, New York.

Ellen, R., Fukui, K., 1996. Redefining Nature. Ecology, Culture and Domestication. Berg, Oxford.

Escobar, A., 1998. Whose knowledge, whose nature? Biodiversity, conservation, and the political ecology of social movements. Journal of Political Ecology 5, 53-82. https:// doi.org/10.2458/v5i1.21397.

Fairhead, J., Leach, M., 1996. Misreading the African Landscape: Society and Ecology in a Forest-Savanna Mosaic. Cambridge University Press, Cambridge.

Fernández-Llamazares, Á., Cabeza, M., 2018. Rediscovering the potential of indigenous storytelling for conservation practice. Conservation Letters 11, 1-12. https://doi.org/ 10.1111/conl.12398.

Fernández-Llamazares, Á., Méndez-López, M.E., Díaz-Reviriego, I., McBride, M., Pyhälä, A., Rosell-Melé, A., Reyes-García, V., 2015. Links between scientific framings and local perceptions of climate change in an indigenous society. Clim. Change 131, 307-320. https://doi.org/10.1007/s10584-015-1381-7.

Fischer, J., Abson, D.J., Butsic, V., Jahi Chappell, M., Ekroos, J., Hanspach, J., et al., 2014. Land sparing versus Land sharing: moving forward. Conservation Letters 7 , 149-157. https://doi.org/10.1111/conl.12084.

Fisher, W.R., 1984. Narration as a human communication paradigm: the case of public moral argument. Communication Monographs 51, 1-22. https://doi.org/10.1080/ 03637758409390180.

Game, E.T., Schwartz, M.W., Knight, A.T., 2015. Policy relevant conservation science. Conservation Letters 8 (5), 309-311. https://doi.org/10.1111/conl.12207.

Gammage, W., 2011. The Biggest Estate on Earth: How Aborigines Made Australia. Allen \& Unwin., Sydney.

Garnett, S.T., Burgess, N.D., Fa, J.E., Fernández-Llanazares, Á., Molnár, Z., Robinson, C.J. et al., 2018. A spatial overview of the global importance of indigenous lands for conservation. Nature Sustainability 1, 369-374. https://doi.org/10.1038/s41893018-0100-6.

Gavin, M.C., McCarter, J., Mead, A., Berkes, F., Richard Stepp, J., Peterson, D., Tang, R., 2015. Defining biocultural approaches to conservation. Trends in Ecology \& Evolution 30, 140-145. https://doi.org/10.1016/j.tree.2014.12.005. 
Gavin, M.C., McCarter, J., Berkes, F., Pareake, T., Mead, A., Sterling, E.J., Tang, R., Turner, N.J., 2018. Effective biodiversity conservation requires dynamic, pluralistic partnership-based approaches. Sustainability 10, 1846. https://doi.org/10.3390/ su10061846.

Gorenflo, L.J., Romaine, S., Mittermeier, R.A., Walker-Painemillam, K., 2012. Co-occurrence of linguistic and biological diversity in biodiversity hotspots and high biodiversity wilderness areas. PNAS 109 (21), 8032-8037. https://doi.org/10.1073/pnas. 1117511109.

Green, S.J., Armstrong, J., Bogan, M., Darling, E., Kross, S., et al., 2015. Conservation needs diverse values, approaches, and practitioners. Conservation Letters 8, 385-387. https://doi.org/10.1111/conl.12204.

Guha, R., 2014. Environmentalism: a Global History. Penguin, UK.

Habib, I., 2010. Man and Environment: The Ecological History of India. Tulika Books.

Harmon, D., Maffi, L., 2002. Are linguistic and biological diversity linked? Conservation Biology in Practice 3, 26-27.

Humphreys, D., 2017. Rights of pachamama: the emergence of an earth jurisprudence in the americas. Journal of International Relations and Development 20, 459-484. https://doi.org/10.1057/s41268-016-0001-0.

Hutchinson, A., 2014. The Whanganui River as a legal person. Alternative Law Journal 39, 179-182. https://doi.org/10.1177/1037969X1403900309.

IPBES, 2015. Preliminary Guide Regarding Diverse Conceptualization of Multiple Values of Nature and Its Benefits, Including Biodiversity and Ecosystem Functions and Services. Technical Report, IPBES/4/INF/13.

IPBES, 2019. The IPBES Fellowship Programme. https://www.ipbes.net/ipbesfellowship-programme.

Jeeva, S., Mishra, B.P., Venugopal, N., Kharlukhi, L., Laloo, R.C., 2006. Traditional knowledge and biodiversity conservation in the sacred groves of meghalaya. Indian Journal of Traditional Knowledge 5, 563-568.

Kauffman, C.M., Martin, P.L., 2016. Can rights of nature make development more sustainable? Why some Ecuadorian lawsuits succeed and others fail. World Development 92, 130-142. https://doi.org/10.1016/j.worlddev.2016.11.017.

Kohn, E., 2013. How Forests Think: Toward an Anthropology Beyond the Human. University of California Press, Berkeley.

Kuletz, V., 1998. The Tainted Desert: Environmental and Social Ruin in the American West. Routledge, New York, NY.

Lakoff, G., 2010. Why it matters how we frame the environment. Environmental Communication: A Journal of Nature and Culture 4, 70-81. https://doi.org/10.1080/ 17524030903529749.

Lamb, A., Green, R., Bateman, I., Broadmeadow, M., Bruce, T., et al., 2016. The potential for land sparing to offset greenhouse gas emissions from agriculture. Nature Climate Change 6 (2016), 488-492. https://doi.org/10.1038/NCLIMATE2910.

Lambini, C.K., Heubach, K., 2017. Public engagement: young scientists welcome at IPBES. Nature 550, 457.

Larigauderie, A., Stenseke, M., Watson, R.T., 2016. Biodiversity assessments: IPBES reaches out to social scientists. Nature 532, 313.

Latour, B., 2009. PAndora'S Hope: Essays on the Reality of Science Studies. Harvard University Press.

Mace, G., 2014. Whose conservation? Science 345, 1558-1560. https://doi.org/10.1126/ science.1254704.

Mathez-Stiefel, S.-L., Boillat, S., Rist, S., 2007. Promoting the diversity of worldviews: an ontological approach to biocultural diversity. In: Haverkort, D., Rist, S. (Eds.), Endogenous Development and Biocultural Diversity. The Interplay of Worldviews, Globalization and Locality. Worldviews and Sciences 6, Compas Series, Leusden, Netherlands, pp. 67-81.

Meda, M.R., Hermes, M.S., 2014. The Heart of the Matter: Infusing Sustainability Values in Education: Experiences of ESD with the Earth Charter. Universidad para la Paz.

Meneghini, R., Packer, A.L., 2007. Is there science beyond English? EMBO Rep. 8, 112-116. https://doi.org/10.1038/sj.embor.7400906.

Mortensen, L.F., Petersen, K.L., 2017. Extending the boundaries of policy coherence for sustainable development: engaging business and civil society. Solutions 8 (3).

Moseley, C., 2010. Atlas of the World'S Languages in Danger. UNESCO Publishing., Paris.

Mühlhäusler, P., 2003. English as an exotic language. In: Mair, C. (Ed.), The Politics of English as a World Language. New Horizons in Postcolonial Cultural Studies, Amsterdam \& New York: Rodopi, pp. 67-86.

Mühlhäusler, P., 2001. Babel revisited. In: Fill, A., Mühlhäusler, P. (Eds.), The Ecolinguistics Reader. Language, Ecology and Environment. Continuum, London, pp. 159-164.

Nahuelhual, L., Saavedra, G., Henríquez, F., Benra, F., Vergara, X., Perugache, C., Hasen, F., 2018. Opportunities and limits to ecosystem services governance in developing countries and indigenous territories: the case of water supply in Southern Chile. Environmental Science \& Policy 86, 11-18. https://doi.org/10.1016/j.envsci.2018. 04.012.

Niles, D., Tachimoto, N., 2018. Science and the experience of nature. Nature Sustainability 1, 540-543. https://doi.org/10.1038/s41893-018-0124-y.

Noss, R.F., Dobson, A.P., Baldwin, R., Beier, P., Davis, C.R., et al., 2012. Bolder thinking for conservation. Conserv. Biol. 26, 1-4. https://doi.org/10.1111/j.1523-1739.2011. 01738.x.

Ostrom, E., 2009. A general framework for analysing sustainability of socio-ecological systems. Science 325, 419-422. https://doi.org/10.1126/science.1172133.

Okri, B., 1996. Birds of Heaven. Routledge, London, UK.

Pacheco, D., 2014. "Living-Well in Harmony and Balance With Mother Earth": A Proposal for Establishing a New Global Relationship between Human Beings and Mother Earth. Universidad de la Cordillera, La Paz.

Parotta, J., Trosper, R.L., 2012. Traditional Forest-Related Knowledge: Sustaining Communities, Ecosystems and Biocultural Diversity. Dordrecht: Springer.

Pascual, U., Balvanera, P., Díaz, S., Pataki, G., Roth, E., et al., 2017. Valuing nature's contributions to people: the IPBES approach. Current Opinion in Environmental Sustainability 26-27, 7-16. https://doi.org/10.1016/j.cosust.2016.12.006.

Phalan, B., Onial, M., Balmford, A., Green, R.E., 2011. Reconciling food production and biodiversity conservation: Land sharing and land sparing compared. Science 333,
1289-1291. https://doi.org/10.1126/science.1208742.

Phalan, B., Green, R.E., Dicks, L.V., Dotta, G., Feniuk, C., et al., 2016. How can higheryield farming help to spare nature? Science 351, 450-451. https://doi.org/10.1126/ science.aad0055.

Porter, J., 2014. Native American Environmentalism: Land, Spirit and the Idea of Wilderness. University of Nebraska Press, Lincoln.

Posey, D., 1999. Introduction: culture and nature - the inextricable link. In: Posey, D. (Ed.), Cultural and Spiritual Values of Biodiversity. Intermediate Technology Publications, London, UK.

Reuter, K., Timpte, M., Nesshöver, C., 2016. Disciplinary balance: how to engage social scientists in IPBES. Nature 531. https://doi.org/10.1038/531173c.

Reyes-García, V., Fernández-Llamazares, Á., McElwee, P., Molnár, Z., Öllerer, K., Wilson, S.J., Brondizio, E.S., 2019. The contributions of indigenous peoples and local communities to ecological restoration. Restor. Ecol. 27 (1), 3-8. https://doi.org/10.1111/ rec.12894.

Rosenfeld, C., 2019. From promotheus to gaea: a case for earth-centered language. Language \& Ecology 1-16.

Salmón, E., 2000. Kincentric ecology: indigenous perceptions of the human-nature relationship. Ecol. Appl. 10, 1327-1332. https://doi.org/10.1890/1051-0761(2000) 010[1327:KEIPOT]2.0.CO;2.

Samakov, A., Berkes, F., 2017. Spiritual commons: sacred sites as core of communityconserved areas in Kyrgyzstan. International Journal of the Commons 11, 422-444. https://doi.org/10.18352/ijc.713.

Satterfield, T., Slovic, S., 2004. What'S Nature Worth? Narrative Expressions of Environmental Values. University of Utah Press.

Schoolenberg, M., den Belder, E., Okayasu, S., Alkemade, R., Lundquist, C., Pereira, H., et al., 2018. Report Onf the Workshop 'Next Steps in Developing Nature Futures'. PBL Publication Number: 3411. Netherlands Environmental Assessment Agency, The Hague.

Schultz, B., 2001. Language and the natural environment. In: Fill, A., Mülhäusler, P. (Eds.), The Ecolinguistics Reader: Language, Ecology and Environment, pp. 109-114.

Schuster, R., Germain, R.R., Bennett, J.R., Reo, N.J., Secord, D.L., Arcese, P., 2018. Biodiversity on indigenous lands equals that in protected areas. bioRxiv. https://doi. org/10.1101/321935.

Sheil, D., Boissiére, M., Beaudoin, G., 2015. Unseen sentinels: local monitoring and control in conservation's blind spots. Ecol. Soc. 20, 39. https://doi.org/10.5751/ES07625-200239.

Sithole, B., 2012. The ARPNet Dilly Bag - A Practical Field Guide to Participatory and Other Research Tools for Use by Aboriginal Researcher Practitioners in Australia ARPNet at RIEL, Charles Darwin University, Northern Territory.

Siurua, H., 2006. Nature above people: rolston and "Fortress" conservation in the South. Ethics \& the Environment 11 (1), 71-96.

Spurr, D., 1993. The Rhetoric of Empire: Colonial Discourse in Journalism, Travel Writing Andimperial Administration. Duke University Press.

Stepan, N.L., 2001. Picturing Tropical Nature. Cornell University Press.

Stepp, J.R., Cervone, S., Castaneda, H., Lasseter, A., Stocks, G., Gichon, Y., 2004. Development of a GIS for global biocultural diversity. Policy Matters 13, 267-270.

Sterling, E.J., Filardi, C., Toomey, A., Sigouin, A., Betley, E., et al., 2017. Biocultural approaches to well-being and sustainability indicators across scales. Nature Ecology \& Evolution 1, 1798-1806. https://doi.org/10.1038/s41559-017-0349-6.

Stibbe, A., 2015. Ecolinguistics: Language, Ecology, and the Stories We Live by Routledge, New York, NY.

Strachan, I.G., 2002. Paradise and Plantation: Tourism and Planation in the Anglophone Caribbean (New World Studies). University of Virgina Press, Charlottesville.

Strack, M., 2017. Land and rivers can own themselves. International Journal of Law in the Built Environment 2, 246-259. https://doi.org/10.1108/IJLBE-10-2016-0016.

Takeuchi, K., 2010. Rebuilding the relationship between people and nature: the satoyama initiative. Ecol. Res. 25, 891-897. https://doi.org/10.1007/s11284-010-0745-8.

Tengö, M., Brondizio, S., Elmqvist, T., Malmer, P., Spierenburg, M., 2014. Connecting diverse knowledge systems for enhanced ecosystem governance: the multiple evidence base approach. Ambio 43, 579-591. https://doi.org/10.1007/s13280-0140501-3.

Tengö, M., Hill, R., Malmer, P., Raymond, C.M., Spierenburg, M., et al., 2017. Weaving knowledge systems in IPBES, CBD and beyond lessons learned for sustainability. Current Opinion in Environmental Sustainability 26-27, 17-25. https://doi.org/10. 1016/j.cosust.2016.12.005.

Tietze, S., Dick, S., 2012. The victorious English language: hegemonic practices in the management academy. Journal of Management Inquiry 22 (1), 122-134. https://doi. org/10.1177/1056492612444316.

Tittensor, D.P., Walpole, M., Hill, S.L.L., Boyce, D.G., Britten, G.L., Burgess, N.D., Ye, Y., 2014. A mid-term analysis of progress towards international biodiversity targets. Science 346 (6206), 241-244. https://doi.org/10.1126/science.1257484.

Turnhout, E., Bloomfield, B., Hulme, M., Vogel, J., Wynne, B., 2012. Conservation policy: listen to the voice of experience. Nature 488, 454-455.

Van Noordwijk, M., Namirembe, S., Catacutan, D., Williamson, D., Gebrekirstos, A., 2014. Pricing rainbow, green, blue and grey water: tree cover and geopolitics of climate teleconnections. Current Opinion in Environmental Sustainability 6, 41-47. https:// doi.org/10.1016/j.cosust.2013.10.008.

Welch, D., Welch, L., Piekkari, R., 2005. Speaking in tongues: the importance of language in international management processes. International Studies of Management \& Organization 35, 10-27. https://doi.org/10.1080/00208825.2005.11043723.

Wilson, E.O., 2016. Half-Earth: Our Planet'S Fight for Life. Liveright Publishing., London.

Wright, T.S.A., 2002. Definitions and frameworks for environmental sustainability in higher education. Higher Education Policy 15 205-120.

Wuerthner, G., Crist, E., Butler, T., 2015. Protecting the Wild: Parks and Wilderness, The Foundation for Conservation. Island Press, London.

Zent, E.L., 2015. Unfurling western notions of nature and amerindian alternatives. Ethics in Science and Environmental Politics 15, 105-123. https://doi.org/10.3354/ esep00159. 